\title{
STEM TAPER EQUATION WITH EXTENSIVE APPLICABILITY TO SEVERAL AGE CLASSES OF Pinus taeda L.
}

\author{
Saulo Jorge Téo ${ }^{1 *}$, Sebastião do Amaral Machado², Afonso Figueiredo Filho², Margarida Tomé \\ ${ }^{1 *}$ University of Western Santa Catarina (UNOESC), Xanxerê, Santa Catarina, Brasil - sauloteo@ yahoo.com.br \\ ${ }^{2}$ Federal University of Paraná (UFPR), Curitiba, Paraná, Brasil - samachado@ufpr.br; afig@ufpr.br \\ ${ }^{3}$ Forest Research Centre, School of Agronomy (ISA), University of Lisboa, Lisboa, Portugal - magatome@isa.ulisboa.pt
}

Received for publication: 02/03/2017 - Accepted for publication: 25/04/2018

\begin{abstract}
The aim of this study was to develop stem taper equations for trees of Pinus taeda L. inside and outside bark with extensive applicability to several age classes. Data were obtained from 631 trees of $P$. taeda, ranging from 4 to 31 years of age, in different stands distributed in several counties of the Midwest region of the state of Santa Catarina, Brazil. The taper models of Biging (1984), Schöpfer (1966), and Kozak et al. (1969) were tested. These models were fitted in their simplest formulation as well as by varying their coefficient linear functions of stand age with the procedure PROC NLIN in the software SAS ${ }^{\circledR}$ University Edition. There were no significant differences in accuracy and precision in the estimates between the simplest formulation of the Schöpfer (1966) model and the variation of its coefficient $b$ linear function of age, and thus, the simplest formulation was chosen. Among all taper models tested, the Schöpfer (1966) model presented greater accuracy and precision to estimate diameters inside and outside bark, throughout the stem of Pinus taeda, in the Midwest region of the state of Santa Catarina, Brazil.
\end{abstract}

Keywords: Polynomial models, profile models, fitting of simultaneous equations.

\section{Resumo}

Equação de afilamento de aplicabilidade extensiva a diversas classes de idade para Pinus taeda L. Este estudo teve como objetivo desenvolver equações de afilamento do tronco de Pinus taeda L. com e sem casca, de aplicabilidade extensiva, a diversas classes de idade. Os dados foram provenientes de 631 árvores de Pinus taeda, com idades entre 4 e 31 anos, de diversos povoamentos distribuídos em vários municípios da região Meio-Oeste do estado de Santa Catarina. Foram testados os modelos de afilamento de Biging (1984), Kozak et al. (1969) e Schöpfer (1966), os quais foram ajustados em suas formulações simples e com seus coeficientes função linear da idade das árvores, por meio do procedimento PROC NLIN do aplicativo computacional SAS ${ }^{\circledR}$ University Edition. Não houve diferenças expressivas de precisão e exatidão entre as estimativas do modelo de Schöpfer (1966) simples e com os coeficientes função linear da idade, selecionando-se, então, sua formulação simples. Dentre todos os modelos de afilamento testados, o modelo de Schöpfer (1966) apresentou maior precisão e exatidão para estimativas de diâmetros com e sem casca ao longo do fuste de Pinus taeda, na região Meio-Oeste de Santa Catarina.

Palavras-chave: Modelos polinomiais, modelos de perfil, ajuste de equações simultâneas.

\section{INTRODUCTION}

The volume of timber obtained from a tree depends, ultimately, on its future application, i.e., when it is intended to produce lumber, the usable volume of timber is different to the volume when it is intended to be used as firewood (BATISTA et al., 2014). Thus, the timber volume of a tree depends on its class of use or its timber assortment.

When timber assortment volumes of a forest stand are available, it is possible to plan the optimized sale of the timber, aiming for a greater valuation in the consumer market, and thus maximizing profits. Taper models, which can estimate timber volumes for any assortment, enable production planning, transport logistics, and marketing to be undertaken based on the timber assortment, with the number of logs destined to each specific product measured (COSTA et al., 2016), as well as being an important tool in information management for forestry companies (EISFELD et al., 2008). The shape of a tree or log cannot be determined only by measuring, as the diameter or height; one can only establish indices that represent the shape. Calculation of the shape is possible by measuring stem diameters at different heights and its expression is given by processes involving form quotients, form factors, and taper functions.

Usually, the development of a taper model is restricted to a single species, age class, management type, study region, or even diameter, height, and form classes (EISFELD et al., 2008; SOUZA et al., 2008; MIGUEL et al., 2011; FAVALESSA et al., 2012a; FAVALESSA et al., 2012b; SOUZA et al., 2012; KOHLER et al., 2013; LANSSANOVA et al., 2013; TÉO et al., 2013; DAVID et al., 2014; FIGUEIREDO FILHO et al., 2014a; FIGUEIREDO FILHO et al.,

FLORESTA, Curitiba, PR, v. 48, n. 4, p. 471- 482, out/dez. 2018

Téo. S. J. et.al.

ISSN eletrônico 1982-4688

DOI: $10.5380 /$ rf.v48i4.50996 
2015; COSTA et al., 2016; KOHLER et al., 2016; TERRA et al., 2018). According to Figueiredo Filho et al. (2014b), the use of these equations is recommended for datasets experiencing the same conditions.

To develop equations with greater applicability, Queiroz et al. (2008), using the model identity test, developed a taper equation for Bracatinga (Mimosa scabrella Bentham) having different age classes. Other authors have developed similar assessments to Queiroz et al. (2008) that recommend the adjustment of taper functions by age class for different forest species (KOHLER et al., 2013; FIGUEIREDO FILHO et al., 2015; TERRA et al., 2018). Tomé et al. (2007) attempted to adjust the volume and taper equations for Eucalyptus globulus Labill., in which the parameters were expressed as linear combinations of planting age, planting density, site index, and variables that were indicative of rotation, coppice, and climatically homogeneous regions of Portugal to ensure the extensive applicability of the developed equations.

Thus, the objective of the present study was to develop stem taper equations for trees of Pinus taeda L. inside and outside bark that would have extensive applicability for several age classes in the Midwest region of the state of Santa Catarina, Brazil.

\section{MATERIAL AND METHODS}

The present study was undertaken in stands of $P$. taeda belonging to the company Juliana Florestal Ltd., which is associated with FRAME Madeiras Especiais Ltd. and is based in Caçador, state of Santa Catarina, Brazil. In addition to Caçador, the study area included the municipalities of Calmon, Lebon Régis, Macieira, Rio das Antas, Santa Cecília, and Timbó Grande, which are all located in the Midwest region of the state of Santa Catarina, Brazil.

Based on the Köppen classification, the study region has a Cfb climate type, that is, a wet subtropical zone, oceanic climate, without a dry season and with temperate summers. The average temperature of the hottest month is $19.7{ }^{\circ} \mathrm{C}$ and the coldest month is $11.5^{\circ} \mathrm{C}$, and the annual precipitation is $1,736 \mathrm{~mm}$ (ALVARES et al., 2013). The original vegetation of the study region is a Mixed Ombrophilous Forest, mainly in its formation of Montana Mixed Ombrophilous Forest (IBGE, 2007). The main study area contains soils that are Haplic Cambisols with widely varying depths and drainage, ranging from sharp to imperfect and clayey or very clayey Bruno Nitisol, which are moderately acidic (IBGE, 2007).

Data were obtained from $631 P$. taeda trees, with ages between 4 and 31 years, from several stands distributed in the study area. Of this total, bark thickness data were collected from 519 trees, which were cut to perform the cubage procedure. The remaining 112 trees had their outside bark diameters measured only along the stem, using a Criterion RD 1000 and TruPulse 200B in combination, which allowed the measurements to be obtained in a non-destructive manner without felling the trees. Such equipment was used to reduce the number of felled trees, and thus reduce the costs of data collection for the volume of $P$. taeda trees sampled.

For the 519 P. taeda trees that were felled, diameter measurements were taken of bark and bark thickness at $0.5 \%, 1 \%, 5 \%, 10 \%, 15 \%, 20 \%, 25 \%, 30 \%, 40 \%, 50 \%, 60 \%, 70 \%, 80 \%, 90 \%$, and $95 \%$ of the total height of the tree. For the 112 standing trees, outside bark diameters were measured in the same positions relative to the total height of the tree, up to at least $70 \%$, and the stump height considered was $0.1 \mathrm{~m}$.

The distribution of the $631 P$. taeda trees, cubed at different ages, as well as the values of mean diameter $(\bar{d})$, maximum diameter $\left(d_{\max }\right)$, minimum diameter $\left(d_{\min }\right)$, mean height $(\bar{h})$, maximum height $\left(h_{\max }\right)$ and minimum height $\left(h_{\text {min }}\right)$ are shown in Table 1.

Two sets of data were obtained as the following: 1) 10,489 section-level observations to develop the stem taper equation outside bark diameter and 2) 8,823 section-level observations to develop the inside bark diameter stem taper equation. The adjustment of several other taper models was first made in their simplest formulations to verify the data and to determine the candidate models that obtained the best performance (Table 2).

Adjustments to the models were made with the PROC NLIN procedure in the software program SAS® University Edition. As shown in Table 2, all taper models were adjusted in their simplest formulations and with one of their coefficients as a linear function of age by adjusting the simultaneous equations (Equations 1,2, and 3) for coefficients $a, b$ and $c$ as a linear function of age for the Biging model (1984), respectively. This procedure was also followed for the Kozak et al. (1969) and Schöpfer (1966) models. 
Table 1. Diameter at breast height, total height, and number of trees Pinus taeda L. measured by age class in the Midwest region of the state of Santa Catarina, Brazil.

Tabela 1. Diâmetro à altura do peito, altura total e número de árvores de Pinus taeda L., cubadas por classe de idade, da região Meio Oeste de Santa Catarina.

\begin{tabular}{cccccccc}
\hline Age & $\mathbf{n}$ & $\overline{\boldsymbol{d}}$ & $\boldsymbol{d}_{\max }$ & $\boldsymbol{d}_{\min }$ & $\overline{\boldsymbol{h}}$ & $\boldsymbol{h}_{\max }$ & $\boldsymbol{h}_{\min }$ \\
\hline 4 & 30 & 8.60 & 14.50 & 3.90 & 5.28 & 7.40 & 3.10 \\
5 & 63 & 12.80 & 21.00 & 3.70 & 7.65 & 10.20 & 3.37 \\
6 & 89 & 13.43 & 23.00 & 2.90 & 8.37 & 12.70 & 4.08 \\
7 & 60 & 15.19 & 23.10 & 3.90 & 9.77 & 12.80 & 5.10 \\
8 & 30 & 16.25 & 26.00 & 4.00 & 12.41 & 16.25 & 5.17 \\
9 & 30 & 19.66 & 32.00 & 7.70 & 13.98 & 16.80 & 7.90 \\
10 & 59 & 19.69 & 32.50 & 6.00 & 14.71 & 17.80 & 8.30 \\
11 & 30 & 19.60 & 31.70 & 8.20 & 14.81 & 18.80 & 9.22 \\
12 & 39 & 23.53 & 35.50 & 12.50 & 18.57 & 22.60 & 14.90 \\
14 & 29 & 23.95 & 36.92 & 13.37 & 18.88 & 21.70 & 15.80 \\
16 & 23 & 22.99 & 37.56 & 15.60 & 19.45 & 22.30 & 16.20 \\
18 & 37 & 28.07 & 48.06 & 15.92 & 23.38 & 30.20 & 17.30 \\
21 & 65 & 35.00 & 49.97 & 21.65 & 28.98 & 33.00 & 21.50 \\
26 & 13 & 26.98 & 43.90 & 17.50 & 27.69 & 29.50 & 25.00 \\
27 & 12 & 29.31 & 38.83 & 21.96 & 28.87 & 32.80 & 25.40 \\
30 & 12 & 35.83 & 51.80 & 22.60 & 29.23 & 32.00 & 27.30 \\
31 & 10 & 32.60 & 44.20 & 25.10 & 31.08 & 35.00 & 25.00 \\
\hline
\end{tabular}

Table 2. Taper models tested to estimate stem diameters inside and outside bark of Pinus taeda L. trees.

Tabela 2. Modelos de afilamento testados para estimar os diâmetros com e sem casca de árvores de Pinus taeda L. Author Model

\begin{tabular}{cc}
\hline Author & Model \\
\hline Biging (1984) & $d_{i}=d\left[a+b \ln \left(1-\left(\frac{h_{i}}{h}\right)^{\frac{1}{c}}\left(1-e^{\left.\frac{-a}{b}\right)}\right)\right]\right.$ \\
Kozak et al. (1969) & $d_{i}=d\left[a+b\left(\frac{h_{i}}{h}\right)+c\left(\frac{h_{i}}{h}\right)^{2}\right]^{\frac{1}{2}}$ \\
Schöpfer (1966) & $d_{i}=d\left[a+b\left(\frac{h_{i}}{h}\right)+c\left(\frac{h_{i}}{h}\right)^{2}+f\left(\frac{h_{i}}{h}\right)^{3}+g\left(\frac{h_{i}}{h}\right)^{4}+m\left(\frac{h_{i}}{h}\right)^{5}\right]$
\end{tabular}

$d$ : diameter at breast height outside bark (cm); $h$ : total height $(\mathrm{m}) ; d_{i}$ : diameter, at height $h_{i}$ of the stem of the tree, inside and outside bark (cm); $h_{i}$ : height at position $i$ of the stem of the tree (m); $a, b, c, f, g, m$ : coefficients to be estimated; In: natural logarithm; and $e: 2.718281829 \ldots$

$$
\begin{aligned}
& d_{i}=d\left[a+b \ln \left(1-\left(\frac{h_{i}}{h}\right)^{\frac{1}{c}}\left(1-e^{\frac{-a}{b}}\right)\right)\right] \text { in which, } a=a_{0}+a_{1} t \\
& d_{i}=d\left[a+b \ln \left(1-\left(\frac{h_{i}}{h}\right)^{\frac{1}{c}}\left(1-e^{\frac{-a}{b}}\right)\right)\right] \text { in which, } b=b_{0}+b_{1} t \\
& d_{i}=d\left[a+b \ln \left(1-\left(\frac{h_{i}}{h}\right)^{\frac{1}{c}}\left(1-e^{\frac{-a}{b}}\right)\right)\right] \text { in which, } c=c_{0}+c_{1} t
\end{aligned}
$$

In which: $d_{i}, d, h_{i}, h, a, b, c$ : have been defined above; $a_{0}, a_{1}, b_{0}, b_{1}, c_{0}, c_{1}$ : coefficients to be estimated; and $t$ : age (year).

During the first phase, the best performance model was selected based on the following criteria: adjusted coefficient of determination $\left(R_{a j}^{2}\right)$; relative standard error (syx\%); mean of differences $(M D)$; and analysis of studentized residuals. A graphical analysis of the studentized residuals was performed on the estimated dependent variable $\left(\hat{Y}_{i}\right)$, which was aimed at the uniform distribution of residuals with the absence of patterns and

FLORESTA, Curitiba, PR, v. 48, n. 4, p. 471- 482, out/dez. 2018

Téo. S. J. et.al.

ISSN eletrônico 1982-4688 
heteroscedasticity. Once heteroscedasticity of the model resulting from the adjustment by the ordinary least squares method was detected, the weighted least squares method was adjusted.

The weights tested included various combinations of explanatory variables of the model, based on the protocol described by Parresol (1993), which assumes that the variance of the residuals is an exponential function of multiple explanatory variables of the model, as well as their combinations. To verify whether the studentized residuals had normal distribution or not, a graphical representation of these increasingly ordered values on the theoretical quantiles of the normal distribution was constructed. Once the non-normal distribution of the studentized residuals was verified, the weighted least squares method was adjusted, with weights assigned to the studentized residuals exceeding the interval \pm 2 , based on the method described by Huber (1964) and recommended by Myers (1986).

The best performance model selected during this first phase, both in its simplest form and with variations of its linear age function coefficients, was submitted to validation using PRESS residuals $\left(e_{i,-i}\right)$. The calculation of $e_{i,-i}$ was performed considering the set of data in which the observation " $i$ " was taken from the sample, leaving " $n-1$ " observations, which were used to estimate the coefficients of the models (Equation 4). This procedure continued until all observations were removed one by one, and thus the model was adjusted " $n$ " times (MYERS, 1986).

$$
e_{i,-i}=Y_{i}-\hat{Y}_{i,-i}
$$

In which: $Y_{i}$ : value of the dependent variable for observation $i$; and $\hat{Y}_{i,-i}$ : dependent variable estimated by the model when adjusted without observation $i$.

PRESS residuals are the residuals obtained by the estimation $\hat{Y}_{i,-i}$ and are independent of $Y_{i}$. Thus, the estimation $Y_{i}$ was not used simultaneously in the adjustment and evaluation of the model, being, therefore, a true validation test (MYERS, 1986). For the final selection of the model, via the PRESS residuals, the following validation statistics were calculated: modeling efficiency $(E M)$; average of the PRESS differences $\left(M D_{P R E S S}\right)$; average of the PRESS absolute differences $\left(M A D_{P R E S S}\right)$; and the $5 \%$ and $95 \%$ percentile values of the PRESS residuals.

The efficiency of modeling is a statistic that is analogous with the coefficient of determination and expresses the proportion of variance explained by the model (Equation 5). The average of the PRESS differences indicates the bias of the model (Equation 6), whereas the average absolute PRESS differences indicates the accuracy (Equation 7). The $5 \%$ and $95 \%$ percentile values express the magnitude and symmetry of the distribution of PRESS residuals. Finally, the model for best performance with its coefficients linear function of age was compared to its simplest form by means of the values of $M D_{P R E S S}$ and $M A D_{P R E S S}$ by age class for the different measurements taken from the tree height, i.e., $0 \%, 0.5 \%, 1 \%, 5 \%, 10 \%, 15 \%, 20 \%, 25 \%, 30 \%, 40 \%, 50 \%, 60 \%, 70 \%, 80 \%, 90 \%$, and $95 \%$.

$$
\begin{aligned}
& E M=1-\left[\frac{\sum_{i=1}^{n}\left(Y_{i}-\hat{Y}_{i,-1}\right)^{2}}{\sum_{i=1}^{n}\left(Y_{i}-\bar{Y}\right)^{2}}\right] \\
& M D_{P R E S S}=\frac{\sum_{i=1}^{n}\left(Y_{i}-\hat{Y}_{i,-1}\right)}{n} \\
& M A D_{P R E S S}=\frac{\sum_{i=1}^{n}\left|Y_{i}-\widehat{Y}_{i,-1}\right|}{n}
\end{aligned}
$$

In which: $Y_{i}, \hat{Y}_{i,-i}, n$ : have been defined previously.

\section{RESULTS}

During the adjustment and selection phase of candidate models (Table 2), one observation with very high studentized error was found in all taper models inside and outside bark. Thus, this observation was considered atypical (an outlier) and was eliminated from the dataset utilized in the present study.

Among the models tested, the Schöpfer (1966) model displayed better adjustment $\left(R_{a j}^{2}\right)$ and lower error (syx\%) when estimating the diameters outside bark along the stems of trees of P. taeda. Biging model (1984), however, displayed the lowest bias (MD) (Table 3). It was only possible to adjust the Kozak et al. (1969) model in its simplest formulation because the model did not converge with its coefficients linear function of age (Table 3 ).

To estimate the stem diameter outside bark, there was an improvement, although it was almost insignificant, in the $R_{a j}^{2}$ and syx\% criteria when the adjustments to the Schöpfer (1966) and Biging (1984) models were compared between varying their coefficients according to age with their simplest formulations (Table 3). Schöpfer (1966) and Biging (1984) models with coefficients linear function of age displayed greater bias $(M D)$ when compared to their simplest formulations, apart from the Biging model (1984) varying the coefficient $c$ depending on age.

To estimate the stem diameter inside bark, the Schöpfer (1966) model presented a small advantage over the Biging (1984) model for all selection criteria evaluated (Table 3). In particular, the Schöpfer (1966) model was 
better when coefficient $b$ was varied, with better adjustment $\left(R_{a j}^{2}\right)$ and smaller error (sy $\left.x \%\right)$, when estimating the diameters inside bark in trees of $P$. taeda and when varying the coefficient $m$, which displayed the smallest bias $(M D)$ (Table 3). The worst performance was found in the Kozak et al. (1969) model, which fit only in its simplest formulation. There was a small advantage in the adjustment $\left(R_{a j}^{2}\right)$ and precision $(s y x \%)$ of the Schöpfer (1966) and Biging (1984) models with their coefficients as a linear function of age. However, this advantage was not observed when analyzing the bias $(M D)$ of the models (Table 3 ).

Table 3. Selection statistics of the stem taper models in Pinus taeda L. trees outside and inside bark.

Tabela 3. Estatísticas de seleção dos modelos de afilamento do tronco com e sem casca para árvores de Pinus taeda L.

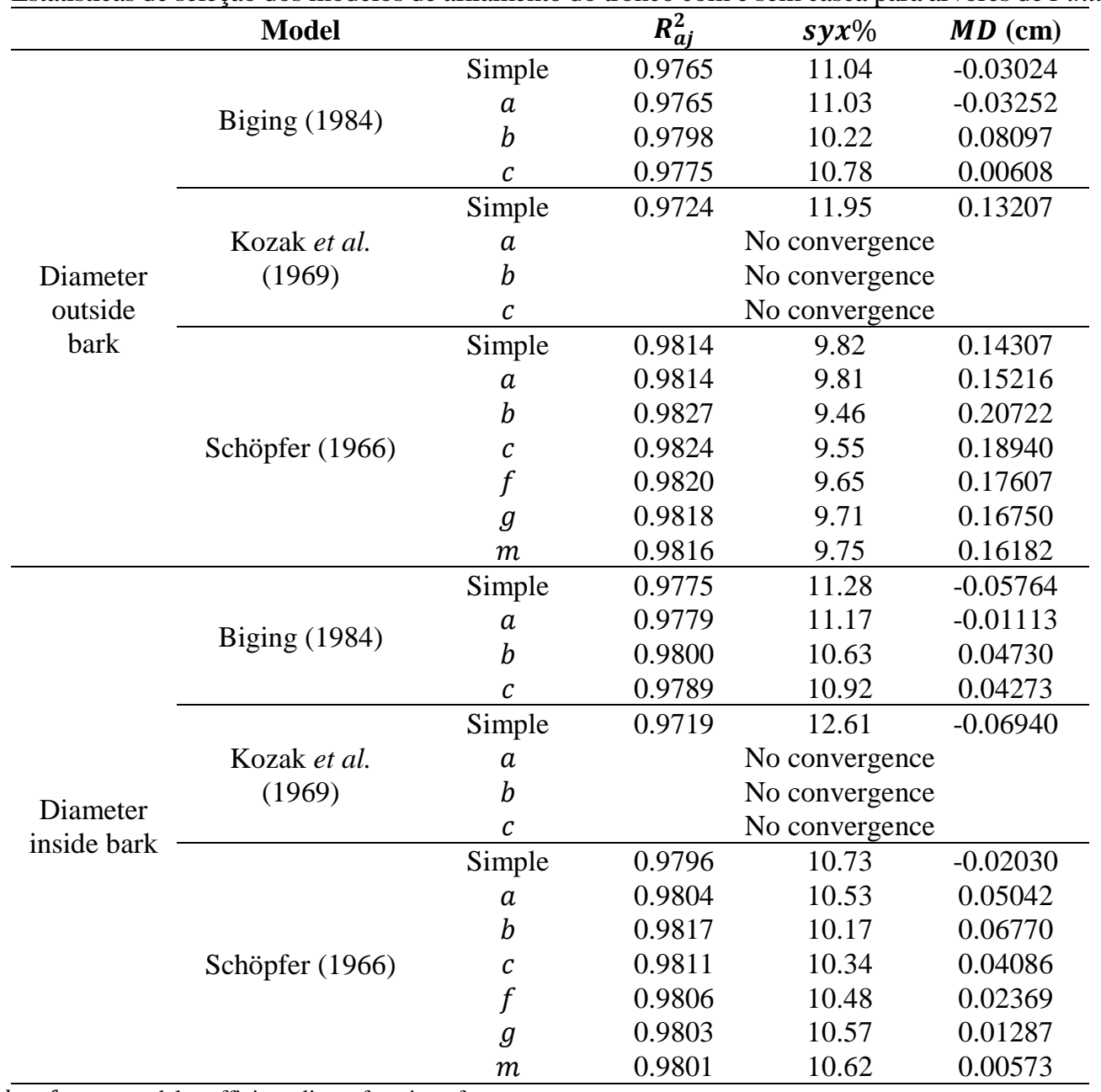

In which: $a, b, c, f, g, m$ : model coefficients linear function of age.

The distribution of the studentized residuals was very similar to the results obtained from the Schöpfer (1966) and Biging (1984) models for all formulations tested to estimate stem diameters of $P$. taeda inside and outside bark. Taking this into consideration, together with the selection criteria (Table 3), we chose to present only the results from the analysis of studentized residuals of the Schöpfer (1966) model (Figure 1), which was selected for the validation phase. When analyzing the dispersion of residuals of the Schöpfer (1966) model on the estimated stem diameters outside bark, there were a few negative diameter values estimated (Figure 1). This occurred for all variants of the Schöpfer (1966) model up to the total height of the tree $\left(h_{i} / h=1\right)$, in which the diameter observed was equal to zero. Moreover, there was a higher frequency of negative values of studentized residuals for the highest values of estimated diameters outside bark $\left(d^{\prime}{ }_{c c}>35 \mathrm{~cm}\right)$, which might indicate a tendency of overestimation when applying this model. Finally, the ordered studentized residuals coincided with the theoretical quantiles of the normal distribution for all variants of the Schöpfer (1966) model after application of the Huber method (1964).

FLORESTA, Curitiba, PR, v. 48, n. 4, p. 471- 482, out/dez. 2018

Téo. S. J. et.al.

ISSN eletrônico 1982-4688

DOI: $10.5380 /$ rf.v48i4.50996 


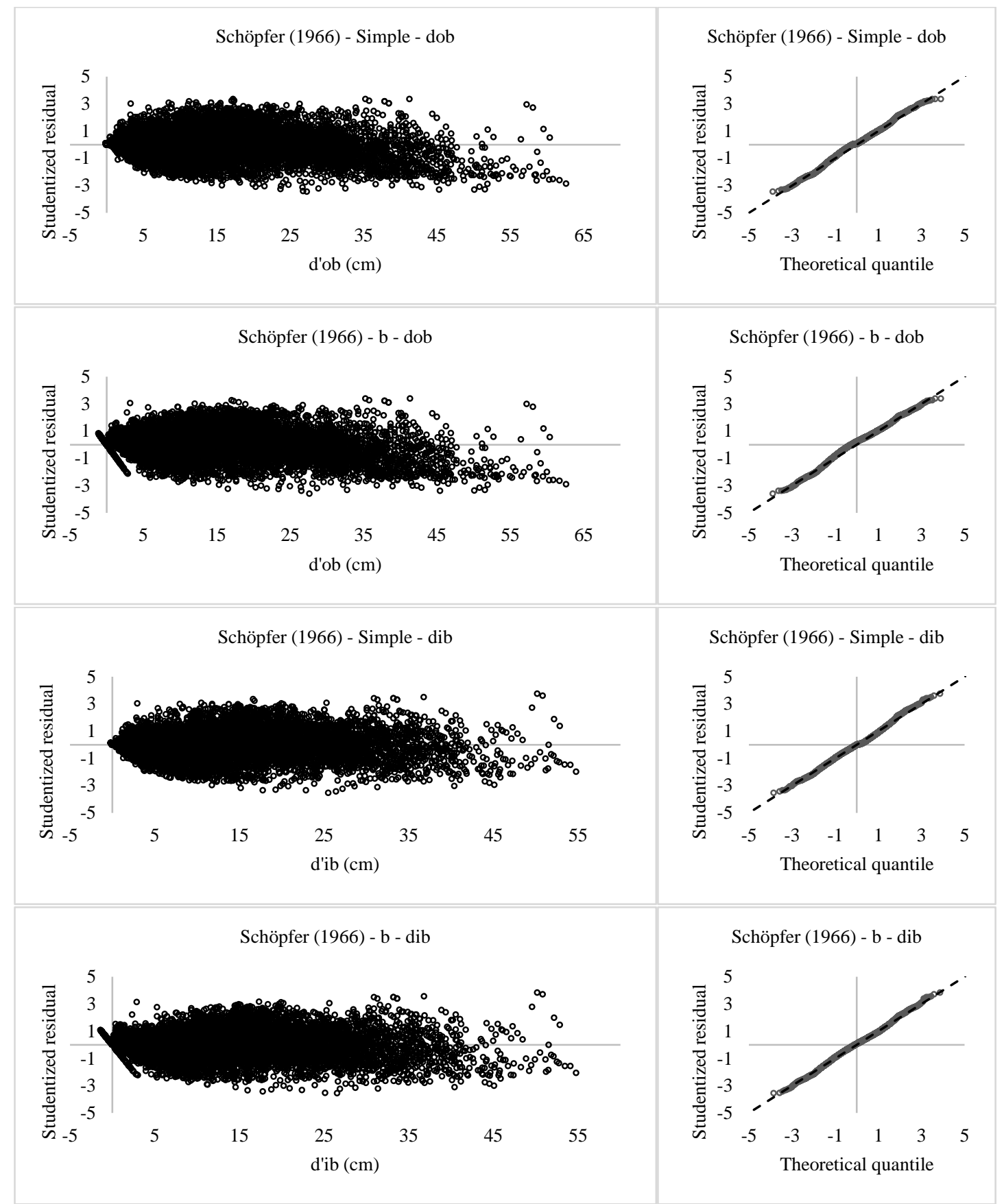

Figure 1. Residual analysis of the Schöpfer model (1966) in its simplest formulation and with variation in the coefficient $b$ linear function of age to estimate stem diameters inside and outside bark of trees of Pinus taeda L.

Figura 1. Análise de resíduos do modelo de Schöpfer (1966) simples e com o coeficiente $b$ função linear da idade para a estimativa de diâmetros com e sem casca de Pinus taeda L.

The dispersion of the studentized residuals on the estimated stem diameters inside bark was uniform. The studentized residuals presented normal distribution for all formulations of the Schöpfer (1966) model, after application of the Huber (1964) method (Figure 1). Similar to the stem diameter outside bark, there were negative values for the estimated stem diameters inside bark when applying the Schöpfer (1966) model varying the coefficient $b$ according to age. However, the distribution of residuals was uniform (Figure 1).

Validation statistics indicated a greater modeling efficiency and accuracy of the estimated stem diameter inside and outside bark for the Schöpfer (1966) model with the coefficient $b$ linear function of age. However, a 
lower bias was presented by the simple Schöpfer model (1966) and varying the coefficient $m$ in the estimation of stem diameters outside and inside bark, respectively. The results for $E M$ and $M A D_{P R E S S}$ were very similar for all variants of the Schöpfer (1966) model (Table 4).

Table 4. Statistics to validate the Schöpfer model (1966) to estimate stem diameters inside and outside bark of trees of Pinus taeda L.

Tabela 4. Estatísticas de validação do modelo de Schöpfer (1966) para estimar diâmetros com e sem casca de árvores de Pinus taeda L.

\begin{tabular}{|c|c|c|c|c|c|c|}
\hline \multirow{2}{*}{ Model } & & \multicolumn{5}{|c|}{ Diameter outside bark } \\
\hline & & $E M$ & $M D_{\text {PRESS }}$ & $M A D_{P R E S S}$ & $P 5$ & $P 95$ \\
\hline \multirow{7}{*}{ Schöpfer (1966) } & Simple & 0.9814 & 0.14252 & 1.08780 & -2.34214 & 2.38289 \\
\hline & $a$ & 0.9814 & 0.15484 & 1.08934 & -2.34649 & 2.38756 \\
\hline & $b$ & 0.9827 & 0.21294 & 1.08056 & -2.23017 & 2.26697 \\
\hline & $c$ & 0.9824 & 0.19381 & 1.08827 & -2.27679 & 2.28266 \\
\hline & $f$ & 0.9820 & 0.17909 & 1.09501 & -2.31032 & 2.32247 \\
\hline & $g$ & 0.9818 & 0.16946 & 1.09749 & -2.32558 & 2.34710 \\
\hline & $m$ & 0.9817 & 0.16300 & 1.09800 & -2.33129 & 2.36514 \\
\hline \multirow{2}{*}{ Model } & & \multicolumn{5}{|c|}{ Diameter inside bark } \\
\hline & & $E M$ & $E M$ & $M D_{\text {PRESS }}$ & $M A D_{\text {PRESS }}$ & $P 5$ \\
\hline \multirow{7}{*}{ Schöpfer (1966) } & Simple & 0.9796 & -0.02388 & 1.05628 & -2.26170 & 2.29914 \\
\hline & $a$ & 0.9804 & 0.05067 & 1.03924 & -2.21405 & 2.31348 \\
\hline & $b$ & 0.9817 & 0.06923 & 1.02280 & -2.14048 & 2.19222 \\
\hline & $c$ & 0.9811 & 0.04135 & 1.04074 & -2.18212 & 2.19512 \\
\hline & $f$ & 0.9806 & 0.02315 & 1.05237 & -2.22561 & 2.24037 \\
\hline & $g$ & 0.9803 & 0.01155 & 1.05798 & -2.23874 & 2.25343 \\
\hline & $m$ & 0.9801 & 0.00379 & 1.06064 & -2.24633 & 2.26424 \\
\hline
\end{tabular}

In which: $a, b, c, f, g, m$ : model coefficients linear function of age.

There were no clear trends in bias $\left(M D_{P R E S S}\right)$ for the two formulations of the Schöpfer (1966) model that were tested to estimate stem diameter outside bark for the different age classes. For several age classes, varying coefficient $b$ in the Schöpfer (1966) model presented greater bias than that in its simplest formulation (Figure 2). As to the accuracy $\left(M A D_{P R E S S}\right)$ by age class, there were differences found in the results between the two formulations of the Schöpfer (1966) model tested. The behavior of the simple Schöpfer model (1966) and varying the coefficient $b$ model was very similar with respect to accuracy and precision analyzed by relative height class (Figure 2). The behavior of the two formulations of the model was also very similar, for both the statistics $M D_{P R E S S}$ and $M A D_{P R E S S}$, from $0 \%$ to $40 \%$ of the height of the tree. There was a slight superiority for the Schöpfer (1966) model varying the coefficient $b$ for the positions of $50 \%$ to $90 \%$ and better performance of the simple Schöpfer (1966) model for positions of $95 \%$ and $100 \%$ (Figure 2).

Regarding the estimates of stem diameter inside bark, the Schöpfer (1966) model with variation of the coefficient $b$ linear function of age presented lower bias for 11 of the 17 age classes analyzed (Figure 2). There were no significant differences in accuracy between the simple Schöpfer (1966) model and the model that varied the coefficient $b$ for estimates of stem diameter inside bark in P. taeda at different ages (Figure 2). The behavior of the two formulations of the model for both the statistics $M D_{P R E S S}$ and $M A D_{P R E S S}$ was very similar from $0 \%$ to $30 \%$ of the height of the tree. There was a slight superiority of the Schöpfer (1966) model that varied coefficient $b$ for the positions of $40 \%$ to $90 \%$ and better performance of the simple Schöpfer (1966) model for the positions of $95 \%$ and $100 \%$ (Figure 2). 

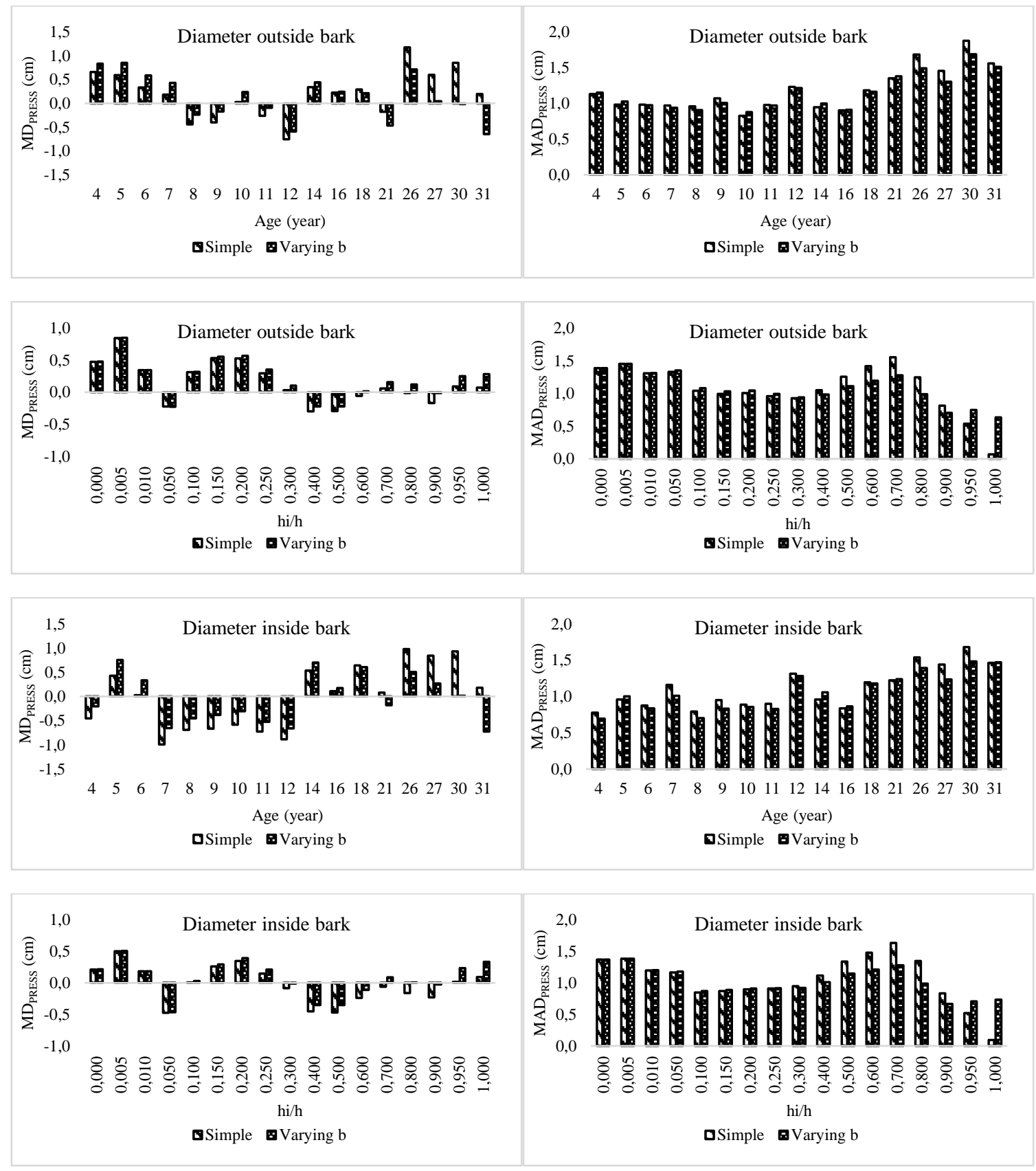

Figure 2. Means of PRESS residual and absolute PRESS residual of the Schöpfer (1966) model in its simplest formulation and with variation in the coefficient $b$ linear function of age, by age and relative height class when estimating the stem diameter inside and outside bark of Pinus taeda L. trees.

Figura 2. Média das diferenças PRESS e média das diferenças absolutas PRESS do modelo de Schöpfer (1966) simples e com o coeficiente $b$ função linear da idade, por classe de idade e altura relativa, para a estimativa de diâmetros com e sem casca de Pinus taeda L.

Based on the selection criteria and validation of the Schöpfer (1966) model, there was no advantage in selecting the more complex formulation to estimate the diameter of $P$. taeda stems inside and outside bark. Thus, the selected equations were derived from the simple Schöpfer (1966) model (Equations 8 and 9).

$$
d_{i o b}=d\left[1.20813-3.58707\left(\frac{h_{i}}{h}\right)+14.87828\left(\frac{h_{i}}{h}\right)^{2}-32.19722\left(\frac{h_{i}}{h}\right)^{3}+30.44277\left(\frac{h_{i}}{h}\right)^{4}-10.74801\left(\frac{h_{i}}{h}\right)^{5}\right]
$$




$$
d_{i i b}=d\left[1.05712-2.73771\left(\frac{h_{i}}{h}\right)+11.71706\left(\frac{h_{i}}{h}\right)^{2}-25.43124\left(\frac{h_{i}}{h}\right)^{3}+23.40369\left(\frac{h_{i}}{h}\right)^{4}-8.01307\left(\frac{h_{i}}{h}\right)^{5}\right]
$$

In which: $d_{i o b}$ : diameter outside bark at height $h_{i}$ of the tree stem $(\mathrm{cm}) ; d_{i i c}$ : diameter inside bark at height $h_{i}$ of the tree stem $(\mathrm{cm})$; and $d, h_{i}, h$ : have been defined previously.

The profiles of the average stem diameter inside and outside bark, generated respectively by Equations 8 and 9, are presented in Figure 3. These profiles represent the shape of $P$. taeda stems, aged 4 to 31 years, in the Midwest region of the state of Santa Catarina, Brazil.

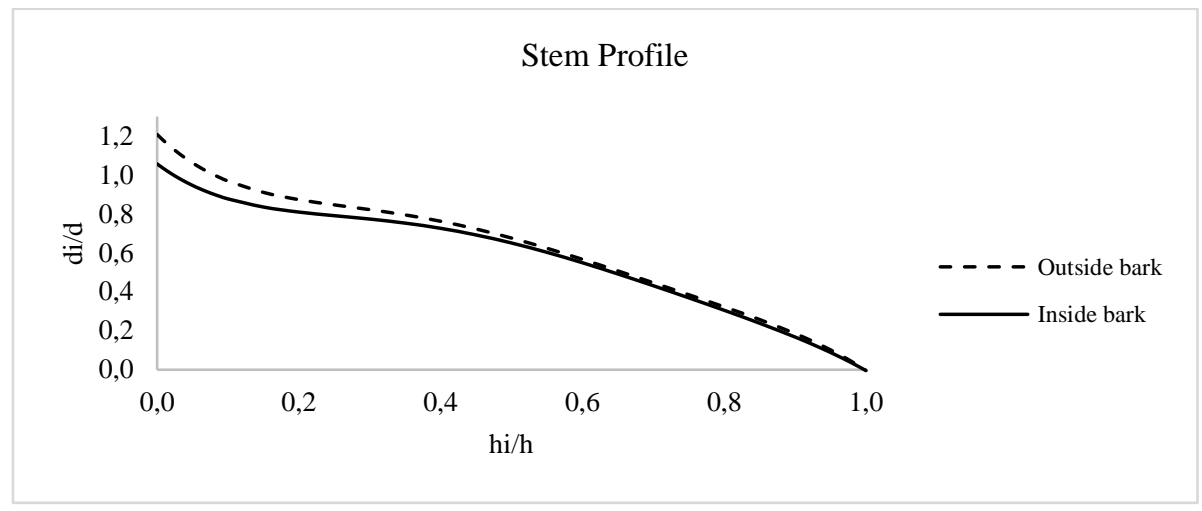

Figure 3. Profiles of stem diameters inside and outside bark produced by the Schöpfer (1966) model for trees of Pinus taeda L. in the Midwest region of Santa Catarina State, Brazil.

Figura 3. Perfil do fuste com e sem casca, gerado pelo modelo de Schöpfer (1966) para árvores de Pinus taeda L., na região Meio Oeste de Santa Catarina.

\section{DISCUSSION}

The values of $R_{a j}^{2}$ and $s y x \%$ for the stem taper equations (Equations 8 and 9) selected in the present study are very similar to those found by Kohler et al. (2013) for the Schöpfer (1966) model adjusted for P. taeda that were 10 to 23 years of age from the state of Santa Catarina. The values of $s y x \%$ in the stem taper functions selected in the present study are slightly higher than those founded by Téo et al. (2013) and Kohler et al. (2013) for the Schöpfer (1966) model adjusted by age class for $P$. elliottii Engelm. and P. taeda, respectively. Except for $M D_{\text {PRESS }}$ for the stem diameter outside bark (Equation 8 ) in the 26 years age class, the statistics $M D$ and $M D_{\text {PRESS }}$ of the stem taper functions (Equations 8 and 9) did not exceed the limit \pm 1 , which according to Souza et al. (2008) is desirable.

Several authors who have undertaken studies with tree taper modeling of different aged trees have recommended the use of a taper equation for each age class owing to better statistical performance of these equations when compared to a general equation (KOHLER et al., 2013; FIGUEIREDO FILHO et al., 2015; KOHLER et al., 2016; TERRA et al., 2018). However, there is an inconvenience associated with using several taper equations simultaneously that was avoided in the modeling approach used in the present study.

Similar to the modeling used in the present study, Tomé et al. (2007) tested several taper models in their simplest formulation and with coefficients as a linear function of climatic and management regimes variables for estimates of diameters inside and outside bark in E. globulus trees from Portugal. At the end of the analysis, these authors recommended the Biging (1984) model in its simplest formulation be utilized. The Schöpfer (1966) model, however, was not tested by Tomé et al. (2007).

The stem taper equation generated by Schöpfer (1966) model varying coefficient $b$ based on age allowed the representation of different stem profiles according to age. This characteristic is extremely desirable, given that the shape of the stem varies according to age (KOHLER et al., 2013; TÉO et al., 2013; FIGUEIREDO FILHO et al., 2014a, 2015; KOHLER et al., 2016). Results from the Schöpfer (1966) model adjusted with the coefficient $b$ linear function of age showed that stem profiles presented lower tapering with higher ages, from approximately $15 \%$ of height, which is in agreement with the results found by Téo et al. (2013) in a study of $P$. elliottii stems in the state of Santa Catarina.

Nevertheless, as only one of the coefficients was a linear function of age each time, the changes were concentrated in only a portion of the stem profile and the remainder remained unchanged according to age. This resulted in lower precision and accuracy of the estimates of diameters inside and outside bark in the uppermost portion of the

FLORESTA, Curitiba, PR, v. 48, n. 4, p. 471- 482, out/dez. 2018

Téo. S. J. et.al.

ISSN eletrônico 1982-4688

DOI: 10.5380/rf.v48i4.50996 
stem (95\% and 100\%) (Figure 2) and estimates of negative diameters for the lower ages and positive for the higher ages at $100 \%$ of height, which is evidenced by the pattern close to the origin of the studentized residuals graph (Figure 1).

\section{CONCLUSIONS}

- Among all the taper models tested, the Schöpfer (1966) model presented higher precision and accuracy of estimates for stem diameters inside and outside bark of trees of P. taeda from the Midwest region of the state of Santa Catarina, Brazil.

- The adjusted Schöpfer (1966) model with coefficients linear function of age did not present any pronounced improvement in the precision and accuracy of the estimates of stem diameters inside and outside bark when compared to its simplest formulation.

\section{ACKNOWLEDGEMENTS}

The authors would like to thank the National Council of Scientific and Technological Development (CNPq), Federal University of Paraná (UFPR), University of Western Santa Catarina (UNOESC), Forest Research Centre (CEF) - CEF is a research unit funded by Fundação para a Ciência e a Tecnologia I.P. (FCT), Portugal (UID/AGR/00239/2013), and to the group FRAMEPORT ${ }^{\circledR}$.

\section{REFERENCES}

ALVARES, C. A.; STAPE, J. L.; SENTElhas, P. C.; GONÇALVES, J. L. M.; SPAROVEK, G. Köppen’s climate classification map for Brazil. Meteorologische Zeitschrift, Stuttgart, v. 22, n. 6, p. 711-728, 2013.

BATISTA, J. L. F.; COUTO, H. T. Z. do; SILVA FILHO, D. F. da. Quantificação de recursos florestais: árvores, arvoredos e florestas. São Paulo: Oficinas de Textos, 2014. 384 p.

COSTA, E. A.; FINGER, C. A. G.; SCHNEIDER, P. R.; HESS, A. F. Função de afilamento e sortimentos de madeira para Araucaria angustifolia. Ciência Florestal, Santa Maria, v. 26, n. 2, p. 523-533, 2016.

DAVID, H. C.; MARINHESKI FILHO, A.; PELISSARI, A. L.; PÉlliCO NETTO, S.; ARAÚJO, E. J. G. de; BAUM, L. Critérios de estratificação para o ajuste de funções de afilamento em fustes de pinus. Pesquisa Florestal Brasileira, Colombo, v. 34, n. 79, p. 197-206, 2014.

EISFELD, R. L.; VIGOLO, D. Z.; SANQUETTA, C. R.; MELLO, A. A. Modelo de Hradetzky aplicado à estimativa do volume total para Araucaria angustifolia (Bert.) O. Ktze. Ambiência, Guarapuava, v. 4, n. 1, p. 51 66, 2008.

FAVAlESSA, C. M. C.; UBIAlli, J. A.; CALDEIRA, S. F.; DRESCHER, R.; ACOSTA, F. C. Equações de sortimentos para Tectona grandis na região Centro-Sul de Mato Grosso. Pesquisa Florestal Brasileira, Colombo, v. 32, n. 72, p. 389-399, 2012a.

FAVALESSA, C. M. C.; UBIALli, J. A.; CALDEIRA, S. F.; DRESCHER, R. Funções de afilamento não segmentadas e segmentadas para Tectona grandis na região Centro-Sul matogrossense. Pesquisa Florestal Brasileira, Colombo, v. 32, n. 72, p. 373-387, 2012 b.

FIGUEIREDO FILHO, A.; KOHLER, S. V.; FELDE, J. L.; DIAS, A. N. Dinâmica do afilamento do tronco e da produção de madeira em plantios de Araucaria angustifolia. Cerne, Lavras, v. 20, n. 4, p. 595-603, 2014 a.

FIGUEIREDO FILHO, A.; MACHADO, S. A.; MIRANDA, R. O. V. de; RETSLAFF, F. A. S. Compêndio de equações de equações de volume e de afilamento de espécies florestais plantadas e nativas para as regiões geográficas do Brasil. Curitiba: Os autores, 2014b. 306 p.

FIGUEIREDO FILHO, A.; RETSLAFF, F. A. S.; KOHLER, S. V.; BECKER, M.; BRANDES, D. Efeito da idade no afilamento e sortimento em povoamentos de Araucaria angustifolia. Floresta e Ambiente, Seropédica, v. 22 , n. 1, p. 50-59, 2015.

HUBER, P. J. Robust estimation of a location parameter. The Annals of Mathematical Statistics, Beachwood, v. 35, n. 1, p. 73-101, 1964.

IBGE - INSTITUTO BRASILEIRO DE GEOGRAFIA E ESTATÍSTICA. Manuais técnicos em geociências: Manual técnico de pedologia. n. 4. 2 ed. Rio de Janeiro: IBGE, 2007. 300 p. 
KOHLER, S. V.; KOEHLER, H. S.; FIGUEIREDO FILHO, A.; ARCE, J. E.; MACHADO, S. A. Evolution of tree stem taper in Pinus taeda stands. Ciência Rural, Santa Maria, v. 46, n. 7, p. 1185-1191, 2016.

KOHLER, S. V.; KOEHLER, H. S.; FIGUEIREDO FILHO, A. Modelos de Afilamento para Pinus taeda por classe de idade. Floresta e Ambiente, Seropédica, v. 20, n. 4, p. 470-479, 2013.

LANSSANOVA, L. R.; UBIALLI, J. A.; ARCE, J. E.; PELISSARI, A. L.; FAVALESSA, C. M. C.; DRESCHER, R. Avaliação de funções de afilamento para estimativa de diâmetro de espécies florestais comerciais do bioma amazônico mato-grossense. Floresta, Curitiba, v. 43, n. 2, p. 215-224, 2013.

MIGUEL, E. P.; MACHADO, S. A.; FIGUEIREDO FILHO, A.; ARCE, J. E. Modelos polinomiais para representar o perfil e o volume do fuste de Eucalyptus urophylla na região Norte do Estado de Goiás. Floresta, Curitiba, v. 41, n. 2, p. 355-368, 2011.

MYERS, R. H. Classical and modern regression with applications. Boston: Duxbury Press, 1986. 359 p.

PARRESOL, B. R. Modeling multiplicative error variance: an example predicting tree diameter from stump dimensions in baldcypress. Forest Science, Bethesda, v. 39, n. 4, p. 670-679, 1993.

QUEIROZ, D.; MACHADO, S. A.; FIGUEIREDO FILHO, A.; ARCE, J. E.; KOEHLER, H. S. Identidade de modelos em funções de afilamento para Mimosa scabrella Bentham em povoamentos nativos da região metropolitana de Curitiba/PR. Floresta, Curitiba, v. 38, n. 2, p. 339-349, 2008.

SOUZA, C. A. M. de; CHASSOT, T.; FINGER, C. A. G.; SCHNEIDER, P. R.; FLEIG, F. D. Modelos de afilamento para o sortimento do fuste de Pinus taeda L. Ciência Rural, Santa Maria, v. 38, n. 9, p. 2506-2511, 2008.

SOUZA, C. A. M. de; FINGER, C. A. G.; SCHNEIDER, P. R.; SILVA, G. F. da; THOMAS, C. Eficiência de um modelo de afilamento ajustado sem e com estratificação por classe de quociente de forma para formação dos sortimentos de Pinus taeda L. Ciência Florestal, Santa Maria, v. 22, n. 1, p. 125-135, 2012.

TÉO, S. J.; MARCON, A.; EHLERS, T.; BIANCHI, J. C.; PELOSO, A.; NAVA, P. R.; COSTA, R. H. da. Modelos de afilamento para Pinus elliottii em diferentes idades, na região de Caçador, SC. Floresta, Curitiba, v. 43, n. 3, p. 439-452, 2013.

TERRA, D. L. C. V.; ANDRADE, V. C. L. de; FREITAS, B. C. Identidade de modelos volumétricos e de afilamento para Corymbia citriodora. Advances in Forestry Science, Cuiabá, v. 5, n. 1, p. 269-274, 2018.

TOMÉ, M.; TOMÉ, J.; RIBEIRO, F.; FAIAS, S. Equação de volume total, volume percentual e de perfil do tronco para Eucalyptus globulus Labill. em Portugal. Silva Lusitana, Lisboa, v. 15, n. 1, p. 25-39, 2007.

FLORESTA, Curitiba, PR, v. 48, n. 4, p. 471- 482, out/dez. 2018

Téo. S. J. et.al.

ISSN eletrônico 1982-4688 
